\title{
HYDROCORTISONE TERTIARY-BUTYLACETATE FOR INTRA-ARTICULAR THERAPY IN RHEUMATIC DISEASES
}

BY

\author{
JACK ZUCKNER, OTAKAR MACHEK, AND ARCH M. AHERN \\ Section on Arthritis, Department of Internal Medicine, Saint Louis University School of Medicine, St. Louis, Mo.
}

(RECEIVED FOR PUBLICATION JULY 10, 1956)

In arthritic individuals who have only one or two peripheral joints causing difficulty, it would seem advisable to treat these joints locally by direct intraarticular injection of medication in an effort to decrease the incidence and severity of toxicity associated with systemic therapy. The first very effective anti-rheumatic preparation for intraarticular injection was hydrocortisone acetate (hereafter referred to as hydrocortisone). Hollander, Brown, Jessar, and Brown (1951), Stevenson, Zuckner, and Freyberg (1952), and Kersley and Desmarais (1952) demonstrated a beneficial response in approximately 70 to 80 per cent. of joints so treated with an average duration of improvement 2 to 3 weeks. Recently, Hollander, Brown, Jessar, Udell, Smukler, and Bowie (1955) reported superior results with a derivative of hydrocortisone, hydrocortisone tertiary-butylacetate* (hereafter referred to as TBA). The purpose of this article is to report our experiences with the intraarticular administration of TBA in 38 patients, eighteen with rheumatoid arthritis, and twenty with osteo-arthritis.

\section{Material and Method}

Hydrocortisone and TBA were supplied for this investigation in the usual saline suspension containing $25 \mathrm{mg} . / \mathrm{ml}$.

Routine surgical preparation was used before each injection. In most instances, ethyl chloride was sprayed over the site of injection for local anaesthesia; infrequently, 1 per cent. procaine was administered. If a large quantity of fluid was to be aspirated, a 20-gauge needle was used; for steroid injection only, a 24-gauge needle was satisfactory. All available fluid was aspirated before the injection of the hormone.

The dose of hormone injected varied from $5 \mathrm{mg}$. into a finger joint to $100 \mathrm{mg}$. into larger articulations. The interval between injections was usually determined by the patient's subjective response, especially the reduction of

* Merck and Co. supplied the hormones used in this study. pain. Effort was made to maintain at least 50 per cent. $\stackrel{\omega}{\mathscr{\omega}}$ decrease of pain and stiffness in the joint treated.

Hydrocortisone and TBA were used alternatively? without the patient's knowledge. Evaluation of the $\vec{~}$ comparative effectiveness of these two steroids was made $\omega$ only if there were at least two injections of each into the N same joint.

Patients were examined once weekly at first, and later은 less often in most instances. A composite estimate in percentage of subjective improvement in pain and $\infty$ stiffness, and also an objective evaluation of range of $\mathbb{D}$ motion, swelling, capsular thickening, tenderness, heat, $\underset{\mathbb{D}}{\vec{B}}$ and degree of synovial fluid in treated joints was recorded.

Altogether 53 joints were treated in 38 patiengs $\vec{\varphi}$ (Table I). Knee joints were injected in the majority of of cases.

TABLE I

DIAGNOSIS OF TREATED JOINTS

\begin{tabular}{|c|c|c|c|c|c|}
\hline & \multirow{2}{*}{ Site } & & & \multicolumn{2}{|c|}{ Number of Joints } \\
\hline & & & & $\begin{array}{l}\text { Rheumatoid } \\
\text { Arthritis }\end{array}$ & Osteo-Arthritis \\
\hline $\begin{array}{l}\text { Knee } \\
\text { Shoulder } \\
\text { Wrist } \\
\text { Elbow } \\
\text { Finger }\end{array}$ & $\begin{array}{l}\cdots \\
\cdots \\
\cdots \\
\cdots\end{array}$ & $\begin{array}{l}\ldots \\
\cdots \\
\ldots \\
\ldots\end{array}$ & $\begin{array}{l}\ldots \\
\cdots \\
\cdots \\
\cdots\end{array}$ & $\begin{array}{r}20 \\
1 \\
1 \\
4 \\
0\end{array}$ & $\begin{array}{r}25 \\
1 \\
0 \\
0 \\
1\end{array}$ \\
\hline
\end{tabular}

One individual was under observation for as long as 3 . 383 days. Patients with rheumatoid arthritis were followed an average of 116 days, osteo-arthritic patients 111 days (Table II).

TABlE II

DURATION OF OBSERVATION

\begin{tabular}{|c|c|c|}
\hline \multirow{2}{*}{ No. of Days Observed } & \multicolumn{2}{|c|}{ Number of Joints } \\
\hline & $\begin{array}{l}\text { Rheumatoid } \\
\text { Arthritis }\end{array}$ & Osteo-Arthritis \\
\hline $\begin{array}{l}0-25 \\
26-50 \\
51-100 \\
101-200 \\
201-300 \\
\text { More than } 300\end{array}$ & $\begin{array}{l}1 \\
4 \\
8 \\
9 \\
3 \\
1\end{array}$ & $\begin{array}{r}4 \\
0 \\
6 \\
14 \\
3 \\
0\end{array}$ \\
\hline
\end{tabular}


TABLE III

NUMBER OF INJECTIONS

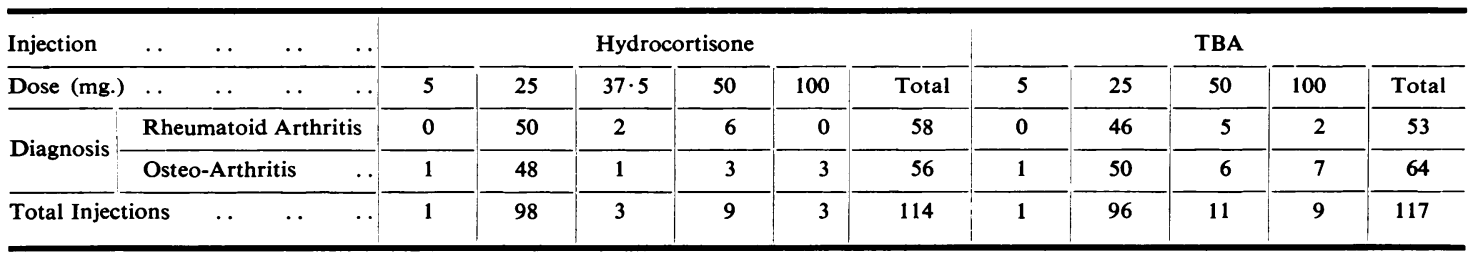

The total number of intra-articular injections was 231 (Table III); 114 were hydrocortisone, and 117 TBA. The most frequently administered dose was $25 \mathrm{mg}$. Twelve $100-\mathrm{mg}$. injections were given.

Two or more injections each of hydrocortisone and TBA were administered in the same 24 joints for comparative studies; half these joints were rheumatoid, and half osteo-arthritic.

\section{Results}

No significant difference between hydrocortisone and TBA could be demonstrated in seventeen of 24 joints in which comparisons were made. Rheumatoid arthritis was present in nine of these articulations and osteo-arthritis in eight. TBA gave better results in five joints and hydrocortisone was superior in two. In no instance was the response to one drug dramatically superior to the other. The immediate improvement and duration of benefit were not significantly greater with either. The average duration of improvement with each drug was 2 to 3 weeks and did not vary with the diagnosis of the treated joint. The results in four rheumatoid and two osteo-arthritic joints were poor with both medications and this form of therapy was discontinued.

Larger doses of TBA in ten joints showed no consistent superiority over smaller doses. Thus, when $100 \mathrm{mg}$. TBA was compared with $25 \mathrm{mg}$. TBA in the same articulation, one joint did slightly better on the larger dose, three surprisingly responded more satisfactorily to the smaller amount, and there was no variation in response in three. In one joint, $100 \mathrm{mg}$. TBA was considered to equal $50 \mathrm{mg}$. TBA; in two other joints, $50 \mathrm{mg}$. TBA equalled $25 \mathrm{mg}$. TBA.

Toxic reactions with TBA were similar to those described with hydrocortisone. An occasional patient complained of increased pain on the evening of an injection, but this was minimal. No infection or systemic toxicity occurred.

\section{Discussion}

Hydrocortisone tertiary-butylacetate (TBA) is another effective agent for intra-articular injection in rheumatic disorders. When compared with hydrocortisone acetate (hydrocortisone), no significant difference in anti-rheumatic action could be demonstrated. The characteristic responses with hydrocortisone are likewise applicable to TBA. Thus, one cannot predict in advance the degree of improvement that will ensue after injections even in the same articulation: Because of this, it was not considered advisable to compare these preparations unless two injections of each hormone were administered in the same joint.

Approximately 80 per cent. of treated rheumatoid or osteo-arthritic joints derive satisfactory benefit from intra-articular TBA. Duration of improvement is variable, averaging 2 to 3 weeks, but lasting in some instances several months. The optimum dose is $25 \mathrm{mg}$. for larger joints. Doses up to 100 mg. did not prove more beneficial. Hip joints were not included in this study, but results might be expected to be generally poorer as with hydrocortisone.

Suitable candidates for this form of therapy include patients with involvement of only one or two peripheral joints, and patients with many diseased joints but only one or two causing marked discomfort. When other medications such as steroids and gold salts are contraindicated, or when some of the systemic measures utilized do not adequately control the symptoms, local intraarticular injections should be given to the more affected joints.

\section{Summary}

(1) Hydrocortisone tertiary-butylacetate gave satisfactory benefit in approximately 80 per cent. of injected rheumatoid and osteo-arthritic joints.

(2) Duration of improvement in the treated joints averaged 2 to 3 weeks.

(3) $25 \mathrm{mg}$. was the optimum dose, even for large articulations.

(4) No significant difference in anti-rheumatic response was demonstrated between hydrocortisone tertiary-butylacetate and hydrocortisone acetate when injected intra-articularly. 
REFERENCES

Hollander, J. L., Brown, E. M., Jr., Jessar, R. A., and Brown, C. Y. (1951). J. Amer. med. Ass., 147, 1629.

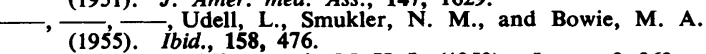
Kersley, G. D., and Desmarais, M. H. L. (1952). Lancet, 2, 269.

Stevenson, C. R., Zuckner, J., and Freyberg, R. H. (1952). Annals of the Rheumatic Diseases, 11, 112.

\section{Le butylacétate tertiaire d'hydrocortisone pour la} thérapie intra-articulaire dans les maladies rhumatismales

\section{RÉSUMÉ}

(1) Le butylacétate tertiaire d'hydrocortisone donna une amélioration satisfaisante dans $80 \%$ de cas d'injections dans des articulations rhumatisantes et ostéoarthritiques.

(2) La durée de l'amélioration dans les articulations traitées était en moyenne de deux à trois semaines.
(3) La dose optima était $25 \mathrm{mg}$., même pour les grosses articulations.

(4) Aucune différence significative dans la réponse antirhumatismale ne fut mise en évidence, entre le $\omega$ butylacétate tertiaire d'hydrocortisone et l'acétate d'hydrocortisone par voie intra-articulaire.

El butilacetato terciario de hidrocortisona para la terapia intra-articular en las enfermedades reumáticas

SUMARIO

(1) El butilacetato terciario de hidrocortisona dió resultados satisfactorios en el $80 \%$ de casos de inyecciones en articulaciones reumáticas y osteoartríticas.

(2) La duración de la mejoría en las articulaciones tratadas fué, en promedio, de dos a tres semanas.

(3) La dosis optima fué $25 \mathrm{mg}$., incluso para las grandes articulaciones.

(4) No se notó diferencia significativa en la respuesta antireumática entre el butilacetato terciario de hidro-? cortisona y el acetato de hidrocortisona por vía oral. 